\title{
PRESSURE AND PRESSURE DERIVATIVE ANALYSIS FOR NON-NEWTONIAN PSEUDOPLASTIC FLUIDS IN DOUBLE-POROSITY FORMATIONS
}

\author{
Freddy-Humberto Escobar ${ }^{1 *}$, Angela-Patricia Zambrano ${ }^{1}$, \\ Diana-Vanessa Giraldo ${ }^{1}$ and José-Humberto Cantillo- Silva ${ }^{2}$ \\ ' Universidad Surcolombiana, Neiva, Huila, Colombia \\ 2 Ecopetrol S.A. - Instituto Colombiano del Petróleo (ICP), A.A. 4185 Bucaramanga, Santander, Colombia
}

e-mail: fescobar@usco.edu.co

(Received Feb. 2, 2011 ; Accepted Apr. 27, 2011)

\section{ABSTRACT}

$\mathbf{N}$ on-Newtonian fluids are often used during various drilling, workover and enhanced oil recovery processes. Most of the fracturing fluids injected into reservoir-bearing formations possess non-

Newtonian nature and these fluids are often approximated by Newtonian fluid flow models. In the field of well testing, several analytical and numerical models based on Bingham, pseudoplastic and dilatant non-Newtonian behavior, have been introduced in the literature to study their transient nature in porous media for a better reservoir characterization. Most of them deal with fracture wells and homogeneous formations. Well test interpretation is conducted via the straight-line conventional analysis or type-curve matching. Only a few studies consider the pressure derivative analysis. However, there is a need for a more practical and accurate way of characterizing such systems. So far, there is no methodology to characterize heterogeneous formation bearing non-Newtonian fluids through well test analysis. In this study, an interpretation methodology using the pressure and pressure derivative log-log plot is presented for non-Newtonian fluids in naturally fractured formations. The dimensionless fracture storativity ratio, $\omega$, and interporosity flow parameter, $\lambda$, are obtained from characteristics points found on such plot. The developed equations and correlations are successfully verified by their application only to synthetic well test data since no actual field data are available. A good match is found between the results provided by the proposed technique and the values used to generate the simulated data.

Keywords: Fracture storativity, Interporosity flow, Behavior index, Power-law, Double-porosity.

Citation: Escobar, F. H., Zambrano, A. P., Giraldo, D. V. \& Cantillo, J. H. (2011). Pressure and pressure derivative analysis for non-newtonian pseudoplastic fluids in double-porosity formations. CT\&F - Ciencia, Tecnología y Futuro, 4 (3), 47 - 60.

*To whom correspondence may be addressed 


\section{RESUMEN}

L

os fluidos no Newtonianos se usan a menudo en varios procesos de perforación, trabajo a pozos y actividades de recobro mejorado. La mayoría de los fluidos de fracturamiento inyectados en los yacimientos que contienen hidrocarburos se comportan no Newtoniamente y, sin embargo, estos fluidos comúnmente se representan en los modelos como modelos fluidos Newtonianos. En el campo de pruebas de presión, se han desarrollado varios modelos numéricos y analíticos que tienen en cuenta el comportamiento no Newtoniano Bingham, pseudoplástico y dilatante, para estudiar la naturaleza transitoria de estos fluidos en una mejor caracterización del yacimiento. Se han propuesto varios modelos numéricos y analíticos para estudiar el comportamiento transitorio de los fluidos no Newtonianos en medios porosos. La mayoría de ellos tratan pozos fracturados y formaciones homogéneas y la interpretación de los datos de presión se conduce mediante el método convencional de la línea recta o ajuste por curvas tipo. Solamente unos pocos estudios consideran análisis con la derivada de presión. Hasta ahora no existe ninguna metodología para caracterizar formaciones heterogéneas mediante pruebas de presión. Sin embargo, hay necesidad de una forma más práctica y exacta de caracterizar estos sistemas. Por lo tanto, este trabajo presenta una metodología de interpretación usando la curva logarítmica de presión y derivada de presión para fluidos no Newtonianos en formaciones naturalmente fracturadas de modo que el coeficiente adimensional de almacenaje, $\omega$, y el parámetro de flujo interporoso, $\lambda$, se obtienen de puntos característicos encontrados en el gráfico log-log de la presión y derivada de presión. Las ecuaciones y correlaciones desarrolladas se verificaron satisfactoriamente mediante su aplicación solo a pruebas de presión sintéticas ya que no existen datos reales reportados en la literatura. Se halló un buen ajuste entre los resultados obtenidos mediante la metodología propuesta y los valores usados para generar la simulación.

Palabras claves: Coeficiente de almacenaje, Flujo interporoso, Comportamiento de flujo, Ley de potencia, Doble porosidad.

\section{RESUMO}

O

fluidos não Newtonianos são usados frequentemente em vários processos de perfuração, trabalho em poços e atividades de recuperação melhorada. A maioria dos fluidos de fraturamento injetados nas jazidas que contêm hidrocarbonetos se comportam não Newtoniamente e, não obstante, estes fluidos são representados normalmente nos modelos como modelos fluidos Newtonianos. No campo de provas de pressão, foram desenvolvidos vários modelos numéricos e analíticos que consideram o comportamento não Newtoniano Bingham, pseudoplástico e dilatante para estudar a natureza transitória destes fluidos para uma melhor caracterização da jazida. Foram propostos vários modelos numéricos e analíticos para estudar o comportamento transitório dos fluidos não Newtonianos em meios porosos. A maioria deles trata poços fraturados e formações homogêneas e a interpretação dos dados de pressão é conduzida mediante o método convencional da linha reta ou ajuste por curvas tipo. Apenas uns poucos estudos consideram análise com a derivada de pressão. Até agora não existe nenhuma metodologia para caracterizar formações heterogêneas mediante provas de pressão. Porém, existe a necessidade de uma forma mais prática e exata de caracterizar estes sistemas. Portanto, este trabalho apresenta uma metodologia de interpretação usando a curva logarítmica de pressão e derivada de pressão para fluidos não Newtonianos em formações naturalmente fraturadas, de modo que o coeficiente adimensional de armazenamento, $\omega$, e o parâmetro de fluxo interporoso, $\lambda$, são obtidos de pontos característicos encontrados no gráfico log-log da pressão e da derivada de pressão. As equações e correlações desenvolvidas foram consideradas satisfatórias mediante sua aplicação individual a provas de pressão sintéticas, já que não existem dados reais registrados na literatura. Encontrou-se um bom ajuste entre os resultados obtidos mediante a metodologia proposta e os valores usados para gerar a simulação.

Palavras chaves: Coeficiente de armazenamento, Fluxo interporoso, Comportamento de fluxo, Lei de potência, Porosidade dupla. 


\section{INTRODUCTION}

Many studies in petroleum and chemical engineering and rheology have focused on non-Newtonian fluid behavior though porous formations. To mention some: Hirasaki and Pope (1974), Ikoku (1979), Ikoku and Ramey (1979a), Odeh and Yang (1979), Savins (1969), and Van Poollen and Jargon (1969). Several numerical and analytical models have been proposed to study the transient behavior of non-Newtonian fluid in porous media. Since all of them were published before the eighties, when the pressure derivative concept was inexistent, interpretation technAlso, the slope of the pressure derivative during radial flow regime is related to the flow behavior index by:

It is worth recognizing that Ikoku has been the researcher who has contributed the most to non-Newtonian power-law fluid modeling, as it is demonstrated in the works of Ikoku (1979), Ikoku and Ramey (1979a, 1979b, ) and Lund and Ikoku (1981). All of these models have been later used by other researchers for further development of well test interpretation techniques. For instance, Vongvuthipornchai and Raghavan (1987) used the pressure derivative function for well test analysis of non-Newtonian fluids, and later on, Katime-Meindl and Tiab (2001) presented the first extension of the TDS technique, Tiab (1993), to non-Newtonian fluids in infinite and faulted homogeneous systems including the effects of wellbore storage and skin factor. Igbokoyi and Tiab (2007) used type-curve matching for interpretation of pressure test for non-Newtonian fluids in infinite systems with skin and wellbore storage effects. Recent applications of the derivative function to nonNewtonian system solutions are presented by Escobar, Martínez, and Montealegre (2010) Martínez, Escobar, and Montealegre (2011) who applied the TDS technique to radial composite reservoirs with a Non-Newtonian/ Newtonian interface for pseudoplastic and dilatants systems, respectively.

As far as non-Newtonian fluid flow through naturally fractured reservoirs is concerned, only a study presented by Olarewaju (1992) is reported in the literature. He presented the analytical solution for the transient behavior of double-porosity infinite formations which bear a non-Newtonian pseudoplastic fluid and his analytical solution also considers wellbore storage effects and skin factor. However, he presented neither well test data interpretation technique nor examples, and his application is only focused on the homogeneous case. In the present work, the analytical solutions with and without wellbore storage and skin introduced by Olarewaju (1992) were used to develop an interpretation technique using the pressure and pressure derivative, so expressions to estimate the Warren and Root (1963) parameters (dimensionless fracture storativity ratio and interporosity flow parameter) are found and successfully tested with synthetic data.

\section{MATHEMATICAL FORMULATION}

\section{Mathematical Model}

The viscosity of a non-Newtonian fluid varies along with pressure and temperature. For a pseudoplastic fluid, the slope of the shear stress versus shear rate decreases progressively and tends to become constant for high values of shear stress. Its most simplistic model is the power law, defined by:

$\tau=k \gamma^{n} ; n<1$

$k$ measures the fluid consistency and $\mathrm{n}$ measures the deviation from the Newtonian behavior. Both parameters differ for each fluid. The governing well pressure solution in the Laplacian domain for a double-porosity system with a non-Newtonian fluid including wellbore storage and skin effects was provided by Olarewaju (1992) as:

$$
\begin{aligned}
& \tilde{P}_{D N N}=\frac{K_{\frac{1-n}{3-n}}\left(\frac{2}{3-n} \sqrt{\tilde{s} f(\tilde{s})}\right)}{\tilde{s}\left((\tilde{s} f(\tilde{s}))^{1 / 2} K_{\frac{2}{3-n}}\left(\frac{2}{3-n} \sqrt{\tilde{s} f(\tilde{s})}\right)\right.} \\
& +\frac{+\sqrt{\tilde{s} f(\tilde{s})} K_{\frac{2}{3-n}}\left(\frac{2}{3-n} \sqrt{\tilde{s} f(\tilde{s})}\right)}{\left.+\tilde{s} C_{D}\left[K_{\frac{1-n}{3-n}}\left(\frac{2}{3-n} \sqrt{\tilde{s} f(\tilde{s})}\right)+s \sqrt{\tilde{s} f(\tilde{s})} K_{\frac{2}{3-n}}\left(\frac{2}{3-n} \sqrt{\tilde{s} f(\tilde{s})}\right)\right]\right)}
\end{aligned}
$$

Without skin and wellbore storage effects, Equation 2 becomes: 


$$
\tilde{P}_{D N N}=\frac{K_{\frac{1-n}{3-n}}\left(\frac{2}{3-n} \sqrt{\tilde{s} f(\tilde{s})}\right)}{\tilde{s}\left(\sqrt{\tilde{s} f(\tilde{s})} K_{\frac{2}{3-n}}\left(\frac{2}{3-n} \sqrt{\tilde{s} f(\tilde{s})}\right)\right)}
$$

The Laplacian parameter, $f(\tilde{s})$ is a function of the model type and fracture system geometry and is given by:

$f(\tilde{s})=\frac{\omega(1-\omega) \tilde{s}+\lambda}{(1-\omega) \tilde{s}+\lambda}$

Once the Laplacian dimensionless pressure function is found, the Stehfest (1970) algorithm is used to invert the data into the real space.

The dimensionless pressure, pressure derivative, time and wellbore storage coefficient functions are defined as:

$$
\begin{gathered}
P_{D N N}=\frac{\Delta P}{141,2(96681,605)^{1-n}\left(\frac{q B}{h}\right)^{n} \frac{\mu_{e f f} r_{w}^{1-n}}{k}} \\
\left(t_{D}^{*} P_{D}^{\prime}\right)_{N N}=\frac{\left(t^{*} \Delta P^{\prime}\right)}{141,2(96681,605)^{1-n}\left(\frac{q B}{h}\right)^{n} \frac{\mu_{e f f} r_{w}^{1-n}}{k}}
\end{gathered}
$$

$t_{D N N}=\frac{t}{G r_{w}^{3-n}}$

$C_{D}=\frac{0,894 C}{h n \phi c_{t} r_{w}^{2}}$

Where:

$$
G=\frac{3792,188 n \phi c_{t} \mu_{e f f}}{k}\left(96681,605 \frac{h}{q B}\right)^{1-n}
$$

And,

$$
\mu_{\text {eff }}=\left(\frac{H}{12}\right)\left(9+\frac{3}{n}\right)^{n}\left(1,59344 \times 10^{-12} k \phi\right)^{(1-n) / 2}
$$

\section{Characteristic Points And Lines}

The methodology for interpretation follows the philosophy of the TDS technique, Tiab (1993), which uses especial features found on the pressure and pressure derivative log-log plot. Katime-Meindel and Tiab (2001) provided expressions for estimation of the wellbore storage coefficient, skin factor and reservoir permeability for homogeneous systems including wellbore storage and skin effects. In this only work, however, their equation for wellbore storage coefficient is applied since the other relationships for permeability and skin factor use the maximum point pressure derivative found during the transition from wellbore storage to radial flow regime. Therefore, if wellbore storage is absent or the early unitslope line is unseen, their equations have no application.

$$
C=\frac{k h t_{i}}{10605,44 e^{-1.85 n} \mu_{e f f}\left(96681,605 \frac{h r_{w}}{q B}\right)^{1-n}}
$$

Escobar et al. (2010) provided equations for reservoir permeability and skin factor for homogeneous systems which can be extended to double-porosity systems as:

$$
\frac{k}{\mu_{e f f}}=\left[70,6(96681,605)^{(1-m)(1-n)}\left(\frac{0,0002637 t_{r 1}}{n \omega \phi c_{t}}\right)^{m}\right.
$$$$
\left.\left(\frac{q B}{h}\right)^{n-m(n-1)}\left(\frac{r_{w}^{m(n-3)+(1-n)}}{\left(t^{*} \Delta P^{\prime}\right)_{r 1}}\right)\right]^{\frac{1}{1-m}}
$$

$$
\begin{aligned}
& \frac{k}{\mu_{\text {eff }}}=\left[70,6(96681,605)^{(1-m)(1-n)}\left(\frac{0,0002637 t_{r 2}}{n \phi c_{t}}\right)^{m}\right. \\
& \left.\left(\frac{q B}{h}\right)^{n-m(n-1)}\left(\frac{r_{w}^{m(n-3)+(1-n)}}{\left(t^{*} \Delta P^{\prime}\right)_{r 2}}\right)\right]^{\frac{1}{1-m}}
\end{aligned}
$$




$$
\begin{aligned}
& s=\frac{1}{2}\left[\left[\frac{0,0002637 k_{1} t_{r 1}}{n \omega \phi \mu_{e f f} c_{t} r_{w}^{3-n}}\left(96681,605 \frac{h}{q B}\right)^{n-1}\right]^{m}\left(\frac{\Delta P}{\left(t^{*} \Delta P\right)}\right)_{r 1}\right. \\
& \left.-\ln \left(\frac{k t_{r 1}}{n \omega \phi \mu_{e f f} c_{t} r_{w}^{3-n}}\left(96681,605 \frac{h}{q B}\right)^{n-1}\right)+7,43\right] \\
& s=\frac{1}{2}\left[\left[\frac{0,0002637 k_{2} t_{r 2}}{n \phi \mu_{e f f} c_{t} r_{w}^{3-n}}\left(96681,605 \frac{h}{q B}\right)^{n-1}\right]^{m}\left(\frac{\Delta P}{\left(t^{*} \Delta P\right)}\right)_{r 2}\right. \\
& \left.-\ln \left(\frac{k t_{r 2}}{n \phi \mu_{e f f} c_{t} r_{w}^{3-n}}\left(96681,605 \frac{h}{q B}\right)^{n-1}\right)+7,43\right]
\end{aligned}
$$

\section{Where $m$ is defined by Equation 16.}

Figure 1 displays the dimensionless pressure and pressure derivative behavior for a non-Newtonian fluid in a double-porosity system with wellbore storage and skin effects. Estimation of wellbore storage coefficient and skin factors have been already studied by KatimeMeindl and Tiab (2001) and Escobar et al. (2010) for homogeneous reservoirs and their development can also be applied for naturally fractured systems. Notice in Figure 1 that wellbore storage affects the minimum of the pressure derivative (trough), impacting the estimation of the dimensionless storativity coefficient and with much less impact on the interporosity flow parameter, as found by Tiab, Igbokoyi and Restrepo. (2007). This correction was first presented for Newtonian fluids by Engler and Tiab (1996) and improved later on by Tiab et al. (2007). Both cases can be extended to Non-Newtonian fluids. However, since the mentioned effects have been already dealt with, this paper focused on the estimation of the Warren and Root (1963) parameters.

Figure 2 contains an ideal pressure and pressure derivative $\log$ - $\log$ plot for a Newtonian double porosity system. In such plot, the infinite-acting radial flow regime is represented by a horizontal straight line on the pressure derivative curve. The first segment corres ponds to pressure depletion in the fracture network while the second portion is due to the pressure response of an equivalent homogeneous reservoir. On the other hand, the transition period which displays a trough on the pressure derivative curve during the transition period only depends on the dimensionless storativity ratio, $\omega$.

The characteristic features depicted in Figure 2 are used to adequately characterize the reservoir system as described in detail by Engler and Tiab (1996). In this study, the same points are also taken into account to generate relationships to estimate the flow behavior index, $n$, and the Warren and Root parameters, as well. For completeness purposes, the reader should refer to the works of Katime-Meindel and Tiab (2001) and Escobar et al. (2010) where procedures to determine permeability, skin factor and wellbore storage are carefully provided. In the examples, however, these properties are calculated.

As seen in Figure 2, radial flow for the Newtonian case $(n=1)$ is characterized by a zero-slope straight line on the pressure derivative curve. As the value of $\mathrm{n}$ decreases, the slope of the derivative during radial flow increases as shown in Figures 3 through 5. The dimensionless pressure and dimensionless pressure derivative log-log plot in Figure 3 is given for constant interporosity flow parameter, constant $n$ value and variable dimensionless fracture storativity ratio. It is observed in such plot that the higher $\omega$ the less pronounced the trough. In Figure 4 the effect of variable of the interporosity flow parameter for constant values of dimensionless storativity ratio and flow behavior index is shown. In this plot, it is worth noticing that as the value of $\lambda$ decreases, the transition period shows up later. Finally, Figure 5 shows the effect of changing the value of the flow behavior index for constant values of $\lambda$ and $\omega$. The effect of increasing the slope of the pressure derivative curve is observed as the value of $n$ decreases. Needless to say that neither wellbore storage nor skin effects are considered in Figure 5. 


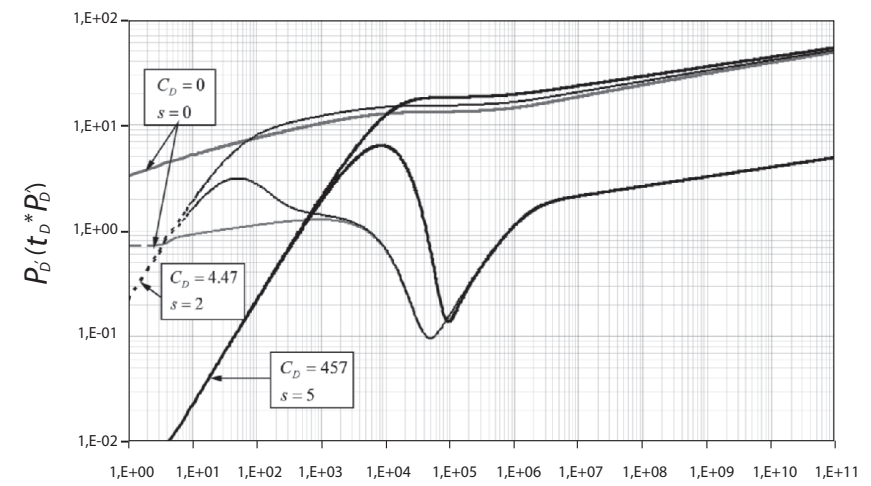

$\left(t_{D}\right)$

Figure 1. Effects of wellbore storage and skin on the dimensionless pressure and pressure derivative for a double-porosity system bearing a Newtonian fluid. $\omega=0,01$ and $\lambda=1 \times 10^{-6}$

The infinite-acting radial flow regime is identified by a straight line which slope increases as the value of the flow behavior index decreases. See Figure 5. The first segment of such line corresponds to the fracturenetwork dominated period, and, the second one (once the transition effects are no longer present) responds for an equivalent homogeneous reservoir. An expression for the slope is given by Ikoku and Ramey (1979b) as:

$m=\frac{n-1}{n-3}$

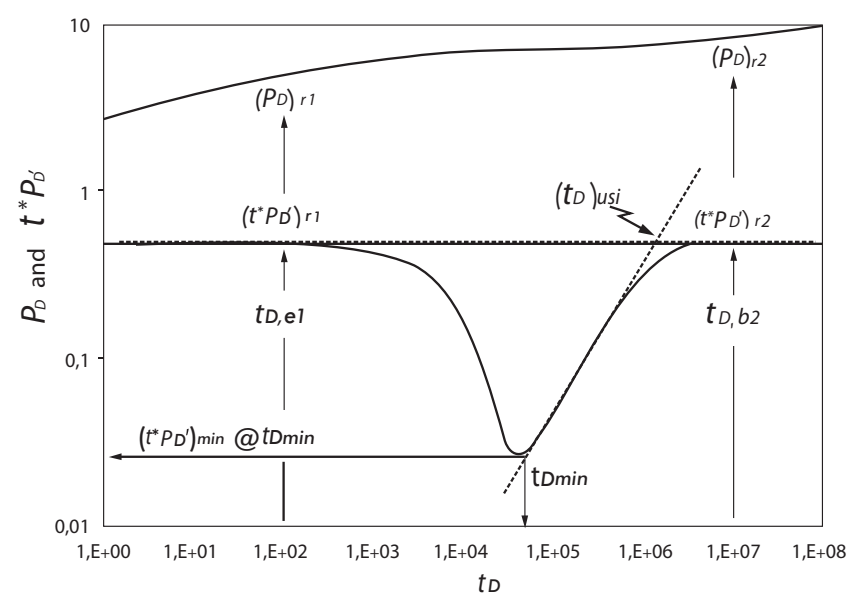

Figure 2. Characteristic points and lines for a naturally fractured reservoirs bearing a Newtonian fluid. $\omega=0,1$ and $\lambda=1 \times 10^{-6}$. After Engler and Tiab (1996)

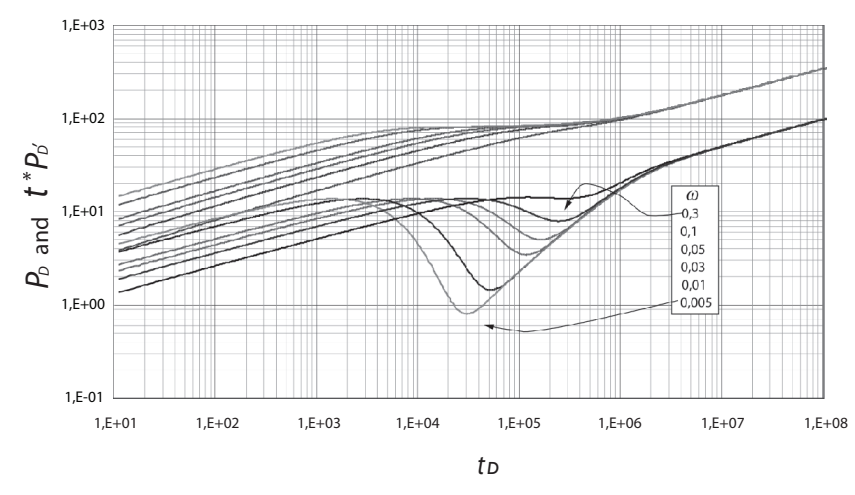

Figure 3. Dimensionless pressure and pressure derivative log-log plot for variable dimensionless storage coefficient, $\lambda=1 \times 10^{-6}$ and $n=0,2$ for a heterogeneous reservoir

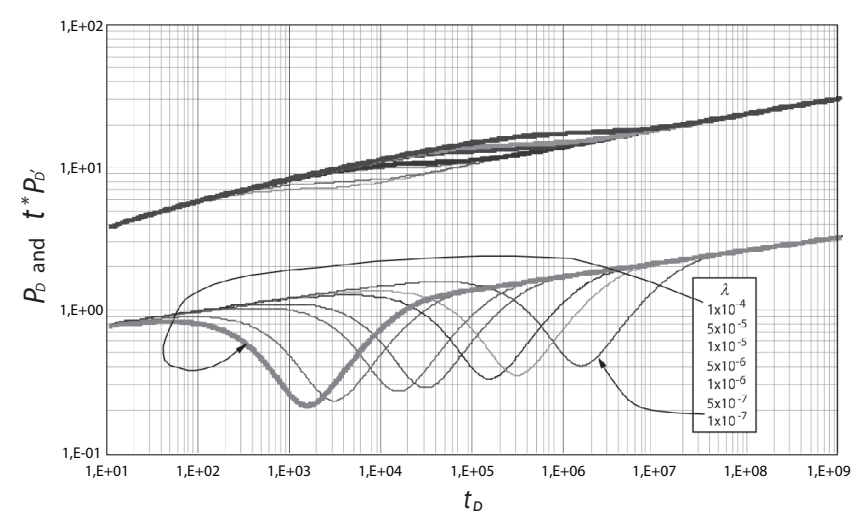

Figure 4. Dimensionless pressure and pressure derivative log-log plot for variable interporosity flow parameter, $\omega=0,05$ and $n=0,8$ for a heterogeneous reservoir

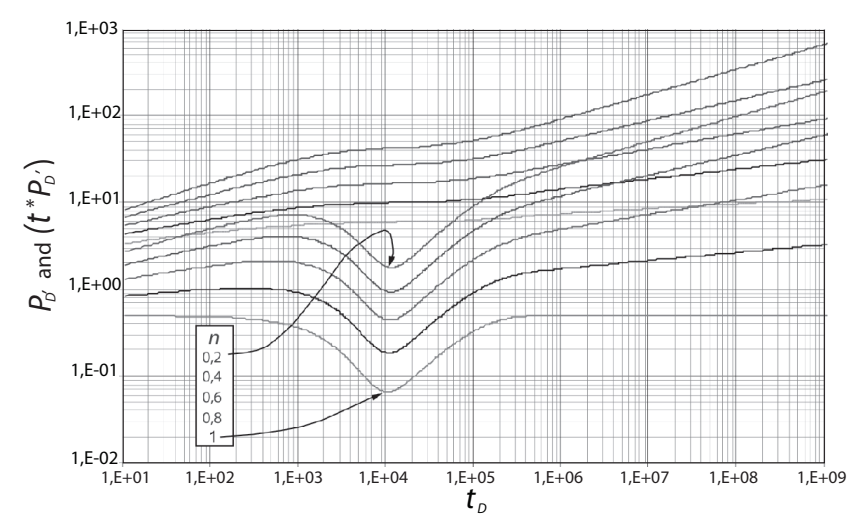

Figure 5. Dimensionless pressure and pressure derivative log-log plot for variable flow behavior index, $\omega=0,03$ and $\lambda=1 \times 10^{-5}$ for a heterogeneous reservoir 
Also, the slope of the pressure derivative during radial flow regime is related to the flow behavior index by:

$$
\begin{aligned}
& n=-1,8783425-7,8618321 m^{3} \\
& +0,19406557 m^{0.5}+2,8783425 e^{-m}
\end{aligned}
$$

\section{Estimation of Parameters}

As observed in Figure 3, as the dimensionless storativity ratio decreases, the transition period is more pronounced no matter the value of the interporosity flow parameter. Therefore, this study develops a correlation for $\omega$ as a function of the minimum time value of the pressure derivative during the transition point (trough), the flow behavior index and the beginning of the second of the infinite-acting radial flow regime, as shown here:

$$
\begin{aligned}
& \frac{1}{\omega}=\mid 3180,6369+551,0582\left(\ln \frac{t_{\min }}{t_{b 2}}\right)^{2}-\frac{2053,5888}{x^{0,5}} \\
& +\frac{75,337547}{x}-\frac{1,4787073}{x^{1,5}}-\frac{910,05377}{n^{0,5}} \\
& +\frac{988,80592}{n}-\frac{459,61296}{n^{1,5}}+\frac{73,93695}{n^{2}} \mid
\end{aligned}
$$

The above correlation is valid for $0 \leq \omega \geq 1$ with an error lower than $3 \%$.

Another way to estimate $\omega$ uses a correlation which is a function of the intersection time between the unit-slope pseudosteady-state straight line developed during the transition period, the time at the trough. We also found that this correlation is also valid for $0 \leq \omega \geq 1$ with an error lower than $0,7 \%$.

$$
\begin{aligned}
& \omega=0,019884508-\frac{1,153351}{y}+\frac{43,428536}{y^{2}} \\
& -\frac{555,85387}{y^{3}}+\frac{3232,6805}{y^{4}}-\frac{6716,9801}{y^{5}} \\
& -\frac{0,0093613189}{n}+\frac{0,0042870178}{n^{2}}+\frac{0,00027356586}{n^{3}} \\
& -\frac{0,0005221335}{n^{4}}+\frac{0,000072466135}{n^{5}}
\end{aligned}
$$

A final correlation to estimate $\omega$ valid in the range $0 \leq \omega \geq 1$ with an error lower than $0,4 \%$ is given as follows:

$\omega=\frac{-0,098427346+0,00046337048 y+0,000025063353 y^{2}}{}$

$$
\frac{-0,00000050316996 y^{3}+0,0036057682 n-0,0073959605 n^{2}}{1-0,36468068 y-0,064934748 n-0,047596083 n^{2}}
$$

The interporosity flow parameter also plays an important role in the characterization of double- porosity systems. From Figure 4, it is observed that the smaller the value of $\lambda$ the later the transition period to be shown up. From this observation, a correlation was obtained using the time at the trough and the dimensionless fracture storativity ratio, as presented by the next expression:

$$
\begin{aligned}
& \lambda=\frac{\left(6,9690127 \times 10^{-7}+3,4893658 \times 10^{-8} n-3,2315082 \times 10^{-8} n^{2}\right.}{(1+0,0099353372 n} \\
& \frac{\left.-5,9013807 w+21571690 w^{2}+3,6102987 \times 10^{12} w^{3}\right)}{\left.-3740035,1 w+6,7143604 \times 10^{12} w^{2}\right)}
\end{aligned}
$$

Equation 21 is valid for $1 \times 10^{-4}<\lambda<9 \times 10^{-7}$ with an error lower than $4 \%$. A correlation involving the coordinates of the trough is given as:

$$
\begin{aligned}
& \lambda=-0,00082917155-0,0014247498 n-0,00028717451 z \\
& -0,00077173053 n^{2}-3,2538271 \times 10^{-5} z^{2}-0,0003203949 n z \\
& -0,0001423889 n^{3}-1,212213 \times 10^{-6} z^{3}-1,7831692 \times 10^{-5} n z^{2} \\
& -8,6457217 \times 10^{-5} n^{2} z
\end{aligned}
$$

Which is valid for $1 \times 10^{-4}<\lambda<9 \times 10^{-7}$ with an error lower than $3,7 \%$. Another expression for $\lambda$ within the same mentioned range involving the minimum time of the trough is given for an error lower than $1,3 \%$.

$$
\begin{aligned}
& \ln \lambda=-2,1223034-0,09473309 n+0,077489686 n^{0,5} \ln (n) \\
& -\frac{0,010651118}{n^{0,5}}-\frac{0,043958503}{w^{0,5}}+\frac{1,5653137 \times 10^{-5} \ln w}{w} \\
& +\frac{0,00024143014}{w}+\frac{8,7148736 \times 10^{-9}}{w^{1,5}}-\frac{4,0331364 \times 10^{-13}}{w^{2}}
\end{aligned}
$$


Table 1. Reservoir and fluid data for examples

\begin{tabular}{ccc|}
\hline Parameter & Example 1 & Example 2 \\
C, bbl/psi & $5,37 \times 10^{-6}$ & 0 \\
\hline $\mathrm{s}$ & 0 & 0,5 \\
\hline$r_{w} \mathrm{ft}$ & 0,25 & 0,25 \\
\hline$h, \mathrm{ft}$ & 50 & 50 \\
\hline$\phi, \%$ & 5 & 10 \\
\hline $\mathrm{k}, \mathrm{md}$ & 1000 & 2000 \\
\hline $\mathrm{q}, \mathrm{Bbl} / \mathrm{D}$ & 1000 & 500 \\
\hline$B, \mathrm{rb} / \mathrm{STB}$ & 1,2 & 1,2 \\
\hline $\mathrm{c}_{t}, \mathrm{l} / \mathrm{psi}$ & $1 \times 10^{-6}$ & $0,5 \times 10^{-6}$ \\
\hline$\mu \mathrm{eff}, \mathrm{cp}$ & 1,5 & 3 \\
\hline$\omega$ & 0,05 & 0,01 \\
\hline$\lambda$ & $4,5 \times 10^{-6}$ & $4,5 \times 10^{-6}$ \\
\hline$n$ & 0,76 & 0,54 \\
\hline
\end{tabular}

\section{Synthetic Examples}

\section{Example 1}

Figure 6 contains the pressure and pressure derivative log-log plot for a pressure test simulated with the information given in Table1. We can estimate from these data the dimensionless storativity ratio and the interporosity flow parameter.

\section{Solution}

From Figure 6 the following characteristic points are read:

$t_{\min }=0,0027 \mathrm{hr} \quad t_{b 2}=0,19 \mathrm{hr}$

$t_{U S, i}=0,0211 \mathrm{hr} \quad\left(t^{*} \Delta P^{\prime}\right)_{\min }=10,5 \mathrm{psi}$

Using Equations 6 and 7, the above data are transformed into dimensionless quantities as follows:

$t_{D \min }=27619 \quad t_{D b 2}=851939$

$t_{D U S, i}=300000 \quad\left(t_{D} * P_{D}{ }^{\prime}\right)_{\text {min }}=0,357$

During the infinite-acting radial flow regime the following points were arbitrarily read: $(t)_{r 2}=0,19 \mathrm{hr} \quad\left(\Delta P^{\prime}\right)_{r 2}=490,9 \mathrm{psi} \quad\left(t^{*} \Delta P^{\prime}\right)_{r 2}=63,62 \mathrm{psi}$

A permeability value of $1026 \mathrm{md}$ and skin factor of 3,56 were obtained using Equations 13 and 15, respectively. They agree with the input value of the simulation.

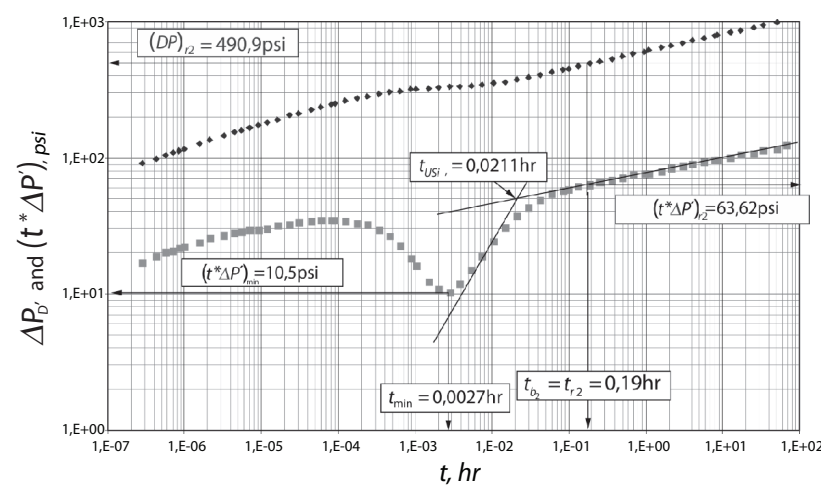

Figure 6. Pressure and pressure derivative log-log plot for synthetic example 1

A slope of $m=0,108$ is estimated with two points on the second straight line portion of the plot. Equation 16 allows obtaining a flow behavior index of 0,759989. The Warren and Root's naturally fractured reservoir parameters are estimated as follows:

Table 2. Summary of results and equations for problem 2

\begin{tabular}{|c|ccc|}
\hline Equation & $\omega$ & Equation & $\lambda$ \\
\hline 18 & 0,0294 & 21 & $5,00 \times 10^{-6}$ \\
\hline 19 & 0,0211 & 22 & $5,04 \times 10^{-7}$ \\
\hline 20 & 0,0197 & 23 & $3,44 \times 10^{-7}$ \\
\hline
\end{tabular}

As expected from non-linear regression analysis, the results were 0,0499 and $4,499 \times 10^{-6}$, for $\omega$ and $\lambda$, respectively.

\section{Example 2}

The pressure and pressure derivative data from Figure 7 were simulated with the information given in Table 1. Using the technique provided in this work, the dimensionless storativity ratio and the interporosity flow parameter can be estimated. 


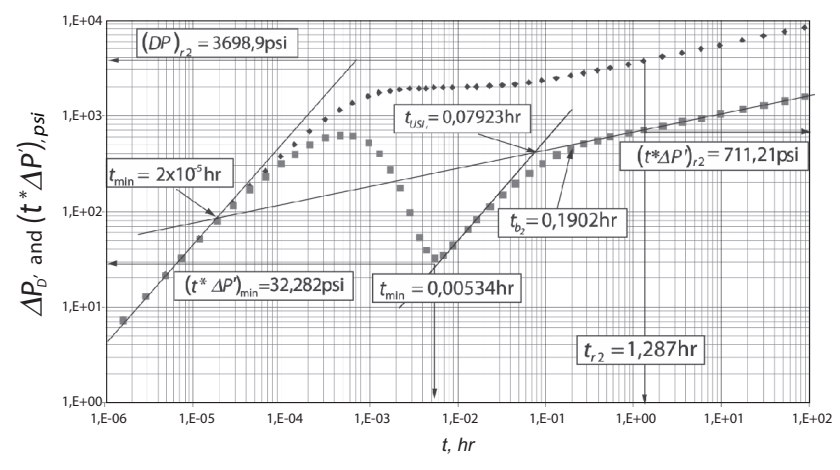

Figure 7. Pressure and pressure derivative log-log plot for synthetic example

\section{Solution}

From Figure 7 the following characteristic points are read:

$$
\begin{array}{ll}
t_{\text {min }}=0,00534 \mathrm{hr} & t_{b 2}=0,19 \mathrm{hr} \\
t_{U S, i}=0,07923 \mathrm{hr} & \left(t^{*} \Delta P^{\prime}\right)_{\min }=32,282 \mathrm{psi}
\end{array}
$$

Again, from Equations 6 and 7, dimensionless quantities are obtained as follows:

$$
\begin{array}{ll}
t_{D \text { min }}=16867 & t_{D b 2}=600000 \\
t_{D U S, i}=250000 & \left(t_{D}{ }^{*} P_{D}{ }^{\prime}\right)_{\text {min }}=0,3836
\end{array}
$$

During the infinite-acting radial flow regime the following points were arbitrarily read:

$$
(t)_{r 2}=1,287 \mathrm{hr}, \quad(\Delta P)_{r 2}=3698,9 \mathrm{psi} \quad\left(t^{*} \Delta P^{\prime}\right)_{r 2}=711,21 \mathrm{psi}
$$

A permeability value of $2043 \mathrm{md}$ and skin factor of 42,1 were obtained using Equations 13 and 15, respectively. The point of intersection, ti, of the early unit-slope line and the radial flow regime has a value of $2 \times 10^{-5} \mathrm{hr}$ which is used in Equation 11 to find a wellbore storage coefficient of $5,37 \times 10^{-6} \mathrm{bbl} / \mathrm{psi}$. As expected, the skin factor value is in disagreement, but the other parameters match the input values for the simulation.

The coordinates are used to estimate a slope $m$ of 0,187 which allows the calculation of a flow behavior index of 0,541 . The dimensionless fracture storativity ratio and the interporosity flow parameter are calculated as reported below:

Table 3. Summary of results and equations for problem 2

\begin{tabular}{|c|c|c|c|}
\hline Equation & $\omega$ & Equation & $\lambda$ \\
\hline 18 & 0,0299 & 21 & $5,010 \times 10^{-6}$ \\
\hline 19 & 0,0303 & 22 & $5,036 \times 10^{-6}$ \\
\hline 20 & 0,0304 & 23 & $3,656 \times 10^{-6}$ \\
\hline
\end{tabular}

For these simulated data, it was explicit to obtain very close results from linear regression analysis. Using this methodology, the results for $\omega$ and $\lambda$ were 0,0989 and $4,5 \times 10^{-6}$ respectively.

\section{ANALYSIS OF RESULTS}

The values of permeability found in the examples analyzed are consistent with the original values. The value of the wellbore storage coefficient also matched well with the value used in the simulation. However, the values of the skin factor did not predict the correct values. From the experience of the authors, this was expected to happen since in naturally fractured reservoirs and fracture wells, the input skin value does not frequently provide same results when interpreted.

As far as the Warren and Root's parameters are concerned, the simulated examples show consistency between the results and those used as input data for the simulations. Although the naturally fractured reservoir parameters are very sensitive, the expressions developed in this work for the estimation of the interporosity flow parameter and the dimensionless storativity ratio reproduce satisfactorily the input used data. Therefore, no error deviation is estimated and the comparison should be performed by simple observation.

As expected, the results obtained from simulation (non-linear regression analysis) agree very well with the input data. 


\section{CONCLUSIONS}

A new methodology based on the pressure derivative is presented to characterize double-porosity formations bearing a non-Newtonian fluid. New equations for estimation of the naturally fractured reservoir parameters were developed and successfully tested with simulated examples. So far, this is the only technique available in the literature for interpreting transient pressure data. Consequently, we recommend the development of other methodologies such as type-curve matching and/or the conventional straight-line method.

\section{ACKNOWLEDGMENTS}

The authors gratefully thank Universidad Surcolombiana and Ecopetrol S.A. - Instituto Colombiano del Petróleo (ICP) for Providing Support for the Completion of this Work.

\section{REFERENCES}

Engler, T. W. \& Tiab, D. (1996). Analysis of Pressure and Pressure Derivate without type curve matching, 4. Naturally Fractured Reservoir, J. Soc. Pet. Eng. (15), 127-138.

Escobar, F. H., Martínez, J. A. \& Montealegre, M. (2010). Pressure and Pressure Derivative Analysis for a Well in a Radial Composite Reservoir with a Non-Newtonian/ Newtonian Interface. CT\&F - Ciencia, Tecnología y Futuro, 4 (2), 33-42.

Hirasaki, G. J., \& Pope, G. A. (1974). Analysis of Factors Influencing Mobility and Adsorption in the Flow of Polymer Solutions through Porous Media. J. Soc. Pet. Eng., 337-346.

Igbokoyi, A. \& Tiab, D. (2007). New type curves for the analysis of pressure transient data dominated by skin and wellbore storage: Non-Newtonian fluid. Paper SPE 106997 presented at the SPE Production and Operations Symposium, Oklahoma, USA. 14.
Ikoku, C. U. (1979). Practical Application of Non-Newtonian Transient Flow Analysis. Paper SPE presented at the SPE 64th Annual Technical Conference and Exhibition, Las Vegas, NV. 8351: 23-26.

Ikoku, C. U. \& Ramey, H. J. Jr. (1979a). Transient Flow of Non-Newtonian Power-law fluids Through in Porous Media. J. Soc. Pet. Eng.164-174.

Ikoku, C. U. \& Ramey, H. J. Jr. (1979b). Wellbore Storage and Skin Effects During the Transient Flow of Non-Newtonian Power-law fluids Through in Porous Media. J. Soc. Pet. Eng.164-174.

Katime-Meindl, I. \& Tiab, D. (2001). Analysis of Pressure Transient Test of Non-Newtonian Fluids in Infinite Reservoir and in the Presence of a Single Linear Boundary by the Direct Synthesis Technique. Paper SPE 71587 prepared for presentation SPE Annual Technical Conference and Exhibition held in New Orleans, Louisiana.

Lund, O. \& Ikoku, C.U. (1981). Pressure Transient Behavior of Non-Newtonian/Newtonian Fluid Composite Reservoirs. J. Soc. Pet. Eng. AIME. 271-280.

Martínez, J. A., Escobar, F. H. \& Montealegre, M. (2011). Vertical Well Pressure and Pressure Derivative Analysis for Bingham Fluids in a Homogeneous Reservoirs. DYNA, $78,(166), 21-28$

Odeh, A. S. \& Yang, H. T. (1979). J. Flow of non-Newtonian Power-Law Fluids Through in Porous Media. J. Soc. Pet. Eng.155-163.

Olarewaju, J. S. (1992). A Reservoir Model of Non-Newtonian Fluid Flow. Unsolicited SPE paper 25301. Soc. Pet. Eng. Richardson, TX, U.S.A. 164-174.

Savins, J. G. (1969). Non-Newtonian flow Through in Porous Media. Industrial \& Engineering Chemistry. 61 (10), $18-47$.

Stehfest, H. (1970). Numerical Inversion of Laplace Transform. Communications of the ACM. 13 (1), 47-49.

Tiab, D. (1993). Analysis of Pressure \& Pressure Derivative without Type-Curve Matching:1- Skin and Wellbore Storage. J. Soc. Pet. Eng. 12, 171-181. Also Paper SPE 25423, Production Operations Symposium held in Oklahoma City, OK. 203-216. 
Tiab, D., Igbokoyi, A. \& Restrepo, D. P. (2007). Fracture Porosity From Pressure Transient Data. Paper IPTC 11164 presented at the International Petroleum Technology Conference held in Dubai, U. A. E. Richardson, TX, U.S.A. 14.

Van Poollen, H. K. \& Jargon, J. R. (1969). Steady-State and Unsteady-State Flow of Non-Newtonian Fluids Through Porous Media. J. Soc. Pet. Eng., 80-88; Trans. AIME, 246.

Vongvuthipornchai, S. \& Raghavan, R. (1987). Well Test Analysis of Data Dominated by Storage and Skin: NonNewtonian Power-Law Fluids. SPE Formation Richardson, 618-627

Warren, J. E. \& Root, P. J. (1963). The Behavior of Naturally Fractured Reservoirs. J. Soc. Pet. Eng., Richardson, 245-255. 


\begin{tabular}{|c|c|}
\hline & NOMENCLATURE \\
\hline$c_{t}$ & System total compressibility, $1 / \mathrm{psi}$ \\
\hline$h$ & Formation thickness, $f t$ \\
\hline$H$ & Consistency (Power-law parameter), $\mathrm{cp}^{*} \mathrm{~s}^{\mathrm{n}-1}$ \\
\hline$k$ & Permeability, md \\
\hline$k$ & Flow consistency parameter \\
\hline$m$ & Slope of the pressure derivative during radial flow regime \\
\hline$n$ & Flow behavior index (power-law parameter) \\
\hline$P$ & Pressure, psi \\
\hline$q$ & Flow/injection rate, STB/D \\
\hline$S$ & Skin factor \\
\hline$\tilde{s}$ & Laplace parameter \\
\hline$T$ & Time, hr \\
\hline$t^{*} \Delta p^{\prime}$ & Pressure derivative, psi \\
\hline$W$ & $\omega / \mathrm{t}_{\text {Dmin }}$ \\
\hline$X$ & $\mathrm{t}_{\min } / \mathrm{t}_{b 2}$ \\
\hline$Y$ & $\mathrm{t}_{U S i} / t_{\min }$ \\
\hline \multirow[t]{2}{*}{$Z$} & $\ln \left[\left(t_{D}{ }^{*} P_{D}{ }^{\prime}\right)_{\min } / \mathrm{t}_{D \min }\right]$ \\
\hline & GREEK \\
\hline$\Delta$ & Change, drop \\
\hline$\omega$ & Dimensionless fracture storativity ratio \\
\hline$\phi$ & Porosity, Fraction \\
\hline$\lambda$ & Interporosity flow parameter \\
\hline$\gamma$ & Shear rate, $\mathrm{s}^{-1}$ \\
\hline$\sigma$ & Shear stress, N/m \\
\hline$\mu$ & Viscosity, cp \\
\hline$\mu_{e f f}$ & Effective viscosity for power-law fluids, $\mathrm{cp}^{*}(\mathrm{~s} / \mathrm{ft})^{\mathrm{n}-1}$ \\
\hline
\end{tabular}




\section{SUFFICES}

App Apparent

b2 Start of the second portion of radial flow regime period

D Dimensionless

E External

eff Effective

$i \quad$ Intercept of the radial flow line with the early unit-slope line

$\min \quad$ Minimum point of the pressure derivative curve

$N \quad$ Newtonian

NN Non - Newtonian

$r 1 \quad$ During first portion of radial flow regime period

$r 2 \quad$ During second portion of radial flow regime period

$u s, i \quad$ Intercept of the unit-slope during the transition period and the second portion of the radial line

w Wellbore 
